Pedagogía y Saberes No. 50

Universidad Pedagógica Nacional

Facultad de Educación. 2019. pp. 51-61

\title{
What is the Educational Task? Arousing the Desire for Wanting to Exist in the World in a Grown-up Way
}

Artículo de reflexión

¿Cuál es la tarea de la educación? Despertando el deseo de querer existir en el mundo de una manera adulta Qual é o dever da educação? Despertando o desejo de querer existir no mundo de uma maneira adulta

Gert Biesta*

To cite this article:

Biesta, G. (2019). What is the Educational Task? Arousing the Desire for Wanting to Exist in the World in a Grown-up Way. Pedagogía y Saberes, 50, 51-61.

Profesor e investigador del Departamento de Educación y director de investigación de Brunel University London. Su trabajo se centra en la teoría y la filosofía de la educación, así como en el análisis de la política educativa con particular interés en el análisis de cuestiones relacionadas con la democracia y la democratización de la educación. 


\begin{abstract}
Discussions about education often focus on the purposes that should be achieved or the outcomes that should be produced. In this paper I approach the question of the purpose of education differently, by asking what the work of teachers and other educators should focus. The answer I propose is that this work is about arousing the desire in children and young people for wanting to exist in the world in what I refer to as a "grown-up" way. I explain my use of the idea of "grown-up-ness," where I argue that we should not think of this as the outcome of a developmental trajectory but as a way in which human beings can try to exist in and with the world. This suggests, as I explain, that central to the work of education is the interruption of ways in which children and young people are entirely self-centred and self-focused, thus turning them towards the world in which their existence as grown-up subjects can only take place. Education that is focused on this has a task to provide time, space and curricular forms through which children and young people can work "on" their grown-up-ness. And education needs to provide sustenance so that children and young people can be supported and nourished in their task of trying to exist in a grown-up way.
\end{abstract}

\title{
Keywords
}

education; teaching; grown-up-ness; egocentrism; interruption; curriculum

\begin{abstract}
Resumen
Las discusiones sobre educación a menudo están enfocadas en los propósitos que deberían lograrse o en los resultados que deberían producirse. En este artículo abordamos la cuestión del propósito de la educación de forma diferente, al preguntarnos en qué debería enfocarse el trabajo de los profesores y demás educadores. La respuesta que proponemos es que el objetivo de este trabajo es despertar en los niños y en los jóvenes el deseo de querer existir en este mundo, de la forma que denominamos como "adulta". Explicamos nuestra idea de "crecimiento", sobre la que argumentaremos que no deberíamos pensar en ella como el resultado de una trayectoria de desarrollo, sino como una forma en la que los seres humanos pueden tratar de existir en y con el mundo. Esto sugiere que es importante, en el trabajo educativo, interrumpir las formas en las que los niños y los jóvenes están completamente enfocados en sí mismos, llevándolos así al mundo en que solo se puede dar su existencia como sujetos adultos. La educación enfocada en eso tiene la tarea de ofrecer tiempo, espacio y formas curriculares a través de las cuales los niños y los jóvenes puedan trabajar "en" su crecimiento. Adicionalmente, la educación debe proveer sustento para que niños y jóvenes puedan recibir apoyo y nutrirse en su tarea de intentar existir de forma adulta.
\end{abstract}

\section{Palabras clave}

educación; enseñanza; crecimiento; egocentrismo; interrupción; currículo

\section{Resumo}

As discussões sobre educação estão focadas, com frequência, nos propósitos que deveriam ser conquistados ou nos resultados que deveriam ser produzidos. Neste artigo abordamos a questão do propósito da educação de forma diferente, perguntando em que deveria estar focado o trabalho dos professores e outros educadores. A resposta que propomos é que o objetivo deste trabalho é despertar o desejo, nas crianças e jovens, de querer existir nesse mundo, da forma que denominamos como "adulta". Explicamos nossa ideia de "crescimento", sobre a qual argumentamos que não deveríamos pensar nela como o resultado de uma trajetória de desenvolvimento, mas como em uma forma na que os seres humanos podem tentar existir em e com o mundo. Isso sugere que é importante, no trabalho educacional, a interrupção de formas nas que as crianças e os jovens estão inteiramente focados em si mesmos, levando-os assim para o mundo em que sua existência como sujeitos adultos só pode acontecer. A educação focalizada nisso tem a tarefa de fornecer tempo, espaço e formas curriculares através das quais crianças e jovens possam trabalhar "em" seu crescimento. Adicionalmente, a educação precisa prover sustento para que crianças e jovens possam ser apoiados e nutridos em sua tarefa de tentar existir de forma adulta.

\section{Palavras-chave}

educação; ensino; crescimento; egocentrismo; interrupção; currículo 
$\mathrm{I}$ $\mathrm{n}$ this article I explore a simple and, in a sense, very basic question, which I have phrased as the question "What is the educational task?"

I am aware that the phrasing of this question is not ideal, particularly not where it concerns the word task. In a number of Germanic languages, there are much more precise and much more interesting words to denote what I am after. In German there are the words Aufgabe and Auftrag, which are very close to the Dutch words opgave and opdracht. What these words try to hint at are things that need to be done, that are there for us to do when we find ourselves in a certain situation or position, such as the position of being a teacher or educator. This is less about a task that needs to be performed or a job that needs to be done as it is about a responsibility we encounter. Interestingly, the words Gabe and gave actually mean "gift," so that Aufgabe and opgave refer to a task that is given to us, a task that comes with the job, so to speak, or the responsibility that comes with the position. Auftrag and opdracht have the words tragen and dragen in them, which mean "to carry," and that is what the task given to us is asking from us as well. That we carry this task. What I seek to express through the question of the educational task, therefore, is that education is not just anything we want it to be, but that it comes with a particular Aufgabe, a particular responsibility, a particular imperative, we might even say.

The answer I will suggest in this article is that the educational task consists in making the grown-up existence of another human being in and with the world possible. Or, with an even more precise formulation: the educational task consists in arousing the desire in another human being for wanting to exist in and with the world in a grown-up way, that is, as subject. There are at least two aspects to this answer that need further exploration. One is the idea of "grown-up-ness," and the other the use of the word existence. To begin with the latter: to use the word existence means that I wish to focus on the ways in which human beings exist-that is, in short, on how they are, and not on the question who they are. If the latter is the question of identity, the former is the question of subjectivity or, in slightly more accurate terms, it is the question of human subject-ness or of the human "condition" of being-subject. Both questions-the question who I am and the question how I am-are of course legitimate questions, also in the context of education. But they are very different questions, and it is important not to conflate them, neither at the level of concepts-the concepts of "identity" and "subject-ness" are not interchangeable-nor at the level of what these concepts seek to express.

As I will discuss in more detail below, I approach "grown-up-ness" - admittedly a slightly awkward word-not as a developmental stage or the outcome of a developmental trajectory, but in existential terms, that is, as a particular "quality" or way of existing. What distinguishes a grown-up way of existing from a non-grown-up way is that the grown-up way acknowledges the alterity and integrity of what and who is other, whereas in the non-grown-up way this is not "on the radar." The grown-up way acknowledges, in other words, that the world out there is indeed "out there," and is neither a world of our own making nor a world that is just at our disposal, that is, a world with which we can do whatever we want or fancy. "The world" here refers both to the natural and to the social world, both to the world of things and to the world of beings. It refers, more concretely, both to our planet and everything on it, and to the other human beings we encounter on this planet. It refers, with an interesting word proposed by Alfonso Lingis (1994, p. 123), both to the earth and to the "earthlings" inhabiting the earth. To acknowledge the alterity and integrity of this world is not to be understood as an act of generosity on my side to let what and who is other exist. It is, in other words, not my decision to let the world exist or not. It rather is my decision to give the alterity and integrity of the world a place in my life-or not, of course.

What is the justification for suggesting that the educational task is to make the grown-up existence of another human being in and with the world possible? In an absolute sense there is no justification for this and, in this regard, the suggestion is literally groundless. Yet this does not preclude that this suggestion may be meaningful, particularly when compared to alternative views about what the educational task might be. One point to highlight here is that it is actually only in the world that we can really exist, since when we withdraw ourselves from the world, we end up existing only with and for ourselves-which is a rather poor and self-absorbed way of existing, if it is to exist at all. To exist in and with the world, thus, always raises the question of the relationship between my existence and the existence of the world. And here again, at least as a starting point, we can say that to exist in and with the world without making space for what exists there as well, is not really to exist in the world. The challenge, therefore, is to 
exist in the world without considering oneself as the centre, origin or ground of the world-which is exactly how Philippe Meirieu describes the "student subject" (élève-sujet), namely as the one who is able to live in the world, without occupying the centre of the world ${ }^{1}$ (Meirieu, 2007, p. 96).

But perhaps the even more difficult question is why we should think of this as an educational issue, rather than as something that each of us should figure out in our own lives. Why, in other words, should we even consider the suggestion that it would be the task-and hence the responsibility and perhaps even the duty-of one human being to make the grown-up existence of another human being possible? We could respond to this question by referring to the fact that this seems to be what educators have always been doing, that it is key to what it means to be a parent and that it is key to what it means to be a teacher, and that what I am trying to do is simply to explore what this might mean in our times. We could also say that the ambition to make the grown-up existence of another human being possible expresses an interest in freedom and, more specifically, an interest in the freedom of the other, and that this is key to what education ought to be about (Biesta \& Säfström, 2011,). I do think that this is how we might articulate the educational interest and hence the educational task, but I do not think that this automatically amounts to a justification of it. After all, the promise of liberation has too often turned into another exercise of power (see, for example, Spivak, 1988; Biesta, 2010a; and, for a wider discussion, Andreotti, 2011), which means that in these matters we should proceed carefully and with not too many pretensions.

I will present my reflections on the educational task in five relatively brief steps, partly in connection to some ideas I have presented in more detail in earlier publications, and partly highlighting with more precision notions of "existence" and "grownup-ness." I will first look at the notion of subjectivity or subject-ness and will try to articulate what it means to exist "as subject." I will pursue this a little further by arguing next that existential matters are ultimately first person matters rather than matters of theory. I will explain this distinction and indicate what this means for the question of being-subject and more specifically the idea of uniqueness. From here I will turn to the question of what it means to exist in the world - a question I will seek to answer by highlighting what it means not to be in the world. This will allow me to say a bit more about the distinction

1 In French: "Un élève-sujet est capable de vivre dans le monde sans occuper le centre du monde." between grown-up and non-grown-up ways of being in the world and the importance of the distinction between the desired and the desirable. In the fifth and final step, I will reflect on the educational "work" that might contribute to making the grown-up existence of another human being in and with the world possible. I conclude the article with a brief reflection on the role of power and authority in educational relationships and on what this means for teaching and the teacher.

\section{The Subject is Subject}

Given that I have suggested that what we are talking about is the subject-ness of the human being and not its identity, the first question to ask if what it means to be a subject. We can answer this question in two ways, either by looking at the subject itself and then trying to find out what the subject is, or by looking away from the subject and then asking what is means for the subject to exist. Here I pursue the second option, taking inspiration from Sartre's dictum that "existence precedes essence," that is, that we first of all exist, that we "find" ourselves in existence, and that any answer to the question of who we are comes afterwards. ${ }^{2}$ While attempts to answer the question of what the subject is, are not necessarily meaningless, they come, in a sense, always too late in relation to our existence itself. This means that while they might help to clarify dimensions of the human condition, they are not able to ground it. If, taking inspiration from Heidegger, we take the idea of existence in a literal sense, we can already begin to see one aspect of the existence of the subject, namely that to exists as subject does not mean to be with oneself-to be identical with oneself-but rather to be "outside" of oneself, that is, in some way to "stand out" (ek-sist) towards the world and be "thrown" into it.

The main insight I wish to highlight about the existence of the subject and our existence as subject is that, to a large degree, our subject-ness is not in our own hands, which may even mean that it is not in our hands at all. The author who I have found most helpful in making sense of this aspect of our subjectness is Hannah Arendt, particularly her ideas on action (which, in Arendt's work, is a technical term with a very precise definition). Action - which for Arendt (1958) is one of the three modalities of the active life, the vita activa-first of all means to take

2 Sartre writes in Existentialism is a humanism (Sartre, 2007 [1946]) that "man first of all exists, encounters himself, surges up in the world-and defines himself afterwards" (p. 22). 
initiative, that is, to begin something. Unlike many philosophers who emphasise the mortality of the human being, Arendt (1958) looks in the opposite direction, that is, in the capacity of the human to be a beginning and a beginner. Arendt compares action to the fact of birth, since with each birth something "uniquely new" comes into the world (Arendt, 1958, p. 178). But it is not just at the moment of birth that this happens. Through our "words and deeds," we continuously bring new beginnings into the world.

Beginning is, however, only half of what action is about, because whether our beginnings will be of any consequence, whether our beginnings will "come into the world" (Biesta, 2006), depends entirely on whether and how others will take up our beginnings-and "taking up" needs to be understood in the broadest possible sense, so as to include responding to such beginnings, repeating such beginnings, taking such beginnings as a cue for further initiatives, and so on. This is why Arendt (1958, p. 184) writes that the "agent" is not an author or a producer, but a subject in the twofold sense of the word, namely as the one who began an action and the one who suffers from and is literally subjected to its consequences. The upshot of this is that our "capacity" for action-which in this sense is precisely not a capacity we have or possesscrucially depends on the ways in which others take up our beginnings. In this sense, we can say that our subject-ness is not in our own hands, which we might indeed summarise, as Simon Critchely (1999) has done, by saying that "the subject is subject" (p. 63).

Although the uptake by others of our initiatives frustrated our beginnings, Arendt (1958) emphasises again and again that the "impossibility to remain unique masters of what [we] do" (p. 244) is at the very condition and the only condition under which our beginnings can become real, that is, can come into the world. It is therefore also the only condition under which we can come into the world, that is, can exist as subjects. While it might be tempting to want to control the ways in which others take up our beginnings, the problem is that, as soon as we do so, we begin to deprive others of their opportunities for action, their opportunities to begin and to exist as subjects. We would then be after a world where one person can act-can be a subject-and everyone else is just a follower, and hence an object of the one who is subject. Arendt (1958) concludes, therefore, that action is never possible in isolation-which also means that we can never exist as subject in isolation. Arendt (1958) goes even as far as to argue that "to be isolated is to be deprived of the capacity to act" (p. 188). This, in turn, leads her to the simple but profound statement that "plurality is the condition of human action" (p. 8), namely that it is only under the condition of plurality that action for all- and hence subject-ness for all-is possible. It is important not to read this as an empirical statement, but rather as the normative "core" of Arendt's work, which is explicitly committed to a world in which everyone has the opportunity to act and exist as subject (see also Biesta, 2010b).

\section{Uniqueness as Irreplaceability}

Whereas Arendt helps us to give meaning to the idea that our subject-ness is not in our hands but to a large degree dependent on what others do with our initiatives, there are still two limitations to her approach; limitations that in a sense are connected. One limitation is that Arendt provides us with a theory about human subject-ness, and thus approaches the question of subject-ness from what we might call "a third person perspective." While her insights are illuminating, they nonetheless try to give a description of the condition of being-subject from the "outside," so to speak, rather than from the point of view of the existence of the subject itself-which we might refer to as a "first person perspective." The second limitation is that Arendt provides a general account of the condition of human subject-ness rather than an account of each human subject in its uniqueness. To put it a bit crudely: while Arendt gets us closer to understanding what it means for subjects to exist, she does not provide us with an argument for why it might matter that each individual human subject exists. Perhaps these observations sound vague and strange when made in this abstract way. But they are precisely what is at stake in the way in which Emmanuel Levinas approaches the question of human subject-ness, in that he tries to give an "account" of subject-ness, not in the form of a theory but from a first person perspective. Here, subject-ness appears as something $I$ have to "figure out" and that no one else can figure out for me, nor that it is something I can figure out for anyone else. And the key term in Levinas's account is uniqueness.

But uniqueness is a tricky term, as the first inclination we might have is to understand it from a thirdperson perspective, that is, as the question concerning the characteristics and capacities each of us has that make each of us different from everyone else. This we might refer to as the idea of uniqueness-as-difference, which would bring us immediately back to questions of identity and identification and to a perspective on uniqueness from the outside, where, from an abstract point, we can make clear how each human being is in some respect different from every other human 
being. As I read his work, Levinas hints at the need for asking a different question about uniqueness, which is not the question "What makes me unique?"- the question about what I have that makes me different from everyone else-but the question "When does it matter that I am I?". The latter question does precisely not ask about everything I have or possess that would distinguish me from others, but looks for situations, for existential events, where my uniqueness is "at stake" and therefore where $I$ am at stake. The situations Levinas has in mind are those where someone calls upon me in such a way that the call is addressed at $m e$ and no one else. These are situations where the call comes to me, and where it is only $I$ who can respond. They are, in other words, situations where we encounter a responsibility, which is the reason why Levinas (1985) suggests that responsibility is "the essential, primary and fundamental structure of subjectivity" (p. 95).

Alfonso Lingis (1994) provides the helpful example of a case where a friend who is dying asks to see you. Such a question, Lingis argues, is a question that only addressed you, as the friend is not interested in just seeing someone-she wants to see you and no one else. This is a question, therefore, that literally singles you out. It is a question that burdens you with a responsibility. It is for you to take up this responsibility or walk away from it. When Zygmunt Bauman (1993) summarises Levinas's insights by writing that, for Levinas, responsibility is "the first reality of the self" (p. 13), he captures what is going on here extremely well, as we could say that it is only in encounters where there is a responsibility for me that my uniqueness begins to matter, that my uniqueness is "at stake," that $I$ am at stake. Here uniqueness is not a matter of difference-a third person perspective-but a matter of irreplaceability-a first person perspective. Uniqueness, as Levinas puts it, is about doing "what nobody else can do in my place" (Levinas, 1989, p. 202). There is of course no one who can force us to take on the responsibility we encounter. In that regard, it is important to see that Levinas is not describing this as a duty, as something we must do. Nor does he see it as a biological fact, that is, as something we cannot not do. On the contrary, we could say that, in a rather strange sense, human freedom also means that we have the possibility to walk away from the responsibility we find ourselves in, and this is entirely up to each of us individually. We cannot take on this responsibility for another human being, nor can we force another human being to act in a particular way if, that is, we respect their subject-ness, if, that is, we encounter them as subjects in their own right, and not as objects of our actions and intentions (this has important implications for education, to which I will return below).

A final thing to mention here is that the responsibility in relation to which my uniqueness begins to matter always and structurally comes from the outside rather than that it is generated by me. It does not start from a feeling or a need to be responsible for the other or to care for the other. The responsibility in the face of which my uniqueness begins to matter and in response to which I might realise, in that particular, singular moment, my subject-ness, therefore always appears as an interruption of my "immanence,"' an interruption of my being with and for myself. Levinas (1989), in some cases, describes human subject-ness as "the very fracturing of immanence" (p. 204), or in slightly less "strong" language, as the moment where "the Same-drowsy in his identity" is awakened by the other (p. 209).

Both Arendt and Levinas thus try to show how our subject-ness is not in our own hands. But whereas Arendt's account starts from my initiatives and is about how they need to be taken up by others in order to become real, Levinas puts this on its head by showing how the possibility for my subject-ness starts from the outside, and only then becomes an "issue" for me, and only and uniquely for me. And the issue is whether I respond to the responsibility I encounter and, in that moment, "realise" my subjectness, or whether I walk away from it. If Arendt gives us a theory of the way in which our subject-ness is not in our own hands-and thus provides us with a third person perspective-Levinas (1989) gives us something that is more like a phenomenology that engages with the question of subject-ness from a first-person perspective, by showing how subjectness is ultimately a matter for each of us individually to figure out. While, as mentioned, theory might help, theory can never replace the existential question; theory can never replace the existential challenge and can sometimes actually become an excuse for not having to engage with it.

\section{The Middle Ground between World-Destruction and Self-Destruction}

If the previous two sections give us some insights into what it means to exist as subject, I now wish to shift to the second part of my thesis about the educational task, which is the suggestion that what matters educationally is to exist in and with the world in a 
grown-up way. Grown-up-ness, as I have already suggested, has to do with an acknowledgement of what I have referred to as the alterity and integrity of what and who is other. If this acknowledgement is not to be understood as generosity from my side-where I would "allow" the world to exist which, formulated in this way, actually sounds rather arrogant-then how might we make sense of what this means? One way to do this, is through a discussion of what might happen when we-or in Arendtian language: our initiatives-encounter resistance.

The encounter with resistance, that is, the encounter with the fact that something or someone resists our initiatives, is a tremendously important experience as it shows that the world is not just a construction of our mind or our desires, but actually has an existence and hence an integrity of its own. The experience of resistance is, in that regard, a worldly experience; an experience that we are somewhere, not just anywhere. What do we do, or what might we do, when we encounter resistance? Let me look at three possible options.

When our initiatives meet resistance, our first response might be one of irritation in face of the encounter with something that frustrates or blocks our initiatives, or at least limits our ability to execute our initiatives. We might "blame" that which offers resistance for this, and might try to enforce our intentions-we could also say: enforce our willupon that which offers resistance. This is partly what needs to be done in order for our initiatives to become real, to arrive in the world, but if we go too far in enforcing our will upon the world, we reach a point where our own force becomes so strong that it destroys the (integrity of the) very "entity" that offers resistance. If we think of our encounters with the material world, we may find ourselves pushing so hard that the material we want to shape and form breaks under the pressure. In this moment we end up destroying the very thing that offers resistance. We might say, therefore, that at this end of the spectrum of the encounter with resistance there is the risk of world-destruction.

From here we can begin to see what lies at the other end of this spectrum, because a second way to respond to the experience of resistance and, more specifically, to the frustration of this experience, is to withdraw from what offers resistance, to step away from it. This is where, when faced with the experience of resistance, we say that the situation is too complex and too difficult for us, that we don't have the energy or appetite to persevere, and we thus begin to withdraw ourselves from the encounter with what offers resistance-in plain English: we back off. While again there may be good reasons for doing so-as it leaves space for that which offers resistance to exist and be in the world-the risk here is that we ultimately withdraw ourselves from any engagement with the world, and ultimately withdraw ourselves completely from (existence in) the world. In a similar vein, we could say, therefore, that we give up or destroy the very conditions that would allow us to exist in the world in the first place. Hence, the extreme we find here is the risk of self-destruction.

World-destruction and self-destruction are the extreme responses to our encounter with resistance, our encounter with the world; responses where we actually end up outside of the world, in a place of non-existence. They therefore also mark the middle ground where existence-worldly existence, existence in and with the world-is possible and literally takes place. We might refer to this middle ground as "dialogue," as long as we do not think of dialogue as conversation, but as an existential form, a way of being together that seeks to do justice to all partners involved. Dialogue is, in this regard, fundamentally different from a contest. A contest is an existential form aimed at bringing about winners and losers. Also, a contest comes to an end once someone has won, whereas dialogue is an ongoing, never-ending challenge. An ongoing, never-ending Aufgabe, we might say. A contest requires a confined burst of energy; staying in dialogue requires ongoing and sustained energy, attention and commitment.

The middle ground is not an easy place to be, which partly helps to understand the attraction of the extremes of world-destruction and self-destruction, as they provide escapes from the difficulty of existing in and with the world. Sometimes we do need to retreat from the difficult middle ground, perhaps to recharge our batteries or gain a perspective on what we are encountering there. And sometimes there is a need to "push"' for something better, which also shows that the middle ground is not the space where just anything should exist. But it is ultimately only in the middle ground that existence is possible. The middle ground is therefore not a place of pure self-expression, but rather a place where our self-expression encounters limits, interruptions, responses-which all have the quality of the frustration Arendt talks about, and the fracturing of immanence Levinas refers to. But with Levinas we can also say that these experiences awaken us from our drowsy state of being outside of the world, of being just with ourselves. These experiences tell us that we are in it "for real"-where what I do mat- 
ters, where how I am matters, and where $I$ matter. To stay in the middle ground thus requires that we affirm and perhaps even embrace this difficulty as the very difficulty that makes our existence possible. Staying in the middle ground thus requires a desire for a worldly existence, an existence outside of ourselves-ek-sistence. And the educational task, as I have suggested, is to arouse such a desire in another human being.

\section{"Grown-up"-ness, the Desired, and the Desirable}

Given how I have described grown-up-ness in the beginning of this article, that is, not as the outcome of a developmental process but as an existential quality or quality of existing, it may perhaps not be too difficult to see that the middle ground between world-destruction and self-destruction is the place where a grown-up way of being with what and who is other might be achieved. By referring to grownup-ness as something that might be achieved, I am again highlighting the existential thrust of the line of thinking I am putting forward in this article. This means that grown-up-ness is not to be understood as something we can posses or claim to have. It is also not something we can claim to be, if by such a claim we would mean that it is securely in our possession and would permeate everything we do. Whether we manage to achieve a grown-up way of being with what and who is other, is something that is always at stake and always a question. In each new situation we may, after all, fail to engage in a grown-up way, and while it is important that we keep making an effortif, that is, we desire to exist rather than being with ourselves-we can never be certain of the outcome of our efforts, and can even be surprised (and disappointed) by our own actions and responses.

While grown-up-ness is not an ideal term, particularly not because of its reference to processes of growth and thus to the suggestion that grown-upness is the outcome of such a process-which I have argued that it is not-grown-up-ness does refer to a state where we have managed to overcome another way of acting with and responding to what and who is other; a way which I have characterised as nongrown-up, but which we could also call "infantile" (but see below), "egocentric," or with a term suggested by Levinas, "egological," 3 that is, following the logic of the ego, not the logic of what and who is

3 In the English translation, the actual term Levinas uses is "egology" (Levinas, 1969, p. 35). other. The egological way of being is entirely generated by the desires of the ego, without asking-and this is the crucial distinction, whether, how, or to what extent such desires are desirable, both for the ego's existence in and with the world and for the world in and with which the ego seeks to exist.

This means, and this is important, that grownup-ness is not a suppression of desires, but a process through which our desires receive a reality check, so to speak, by asking the question what we desire is desirable for our own lives and the lives we live with others. Such a question-and this is educationally important-always poses itself as an interruption of our desires. Such an interruption partly manifests itself through the experience of resistance, and we could even say that when we encounter resistance we not only encounter the world but at the very same time we encounter the desires we have in relation to the world.

When we encounter resistance we could say that the world is trying to tell us something-and perhaps we could even say that the world is trying to teach us something. But the interruption can also be actively enacted when someone asks us whether what we desire is actually desirable. And of course, we may also reach a situation where this question becomes our own question, where it becomes a living question in our own lives (I return to the educational significance of this below.) In all this, therefore, the ambition is not to eradicate our desires, but to give them a worldly form and quality so that they can support and sustain a grown-up way of being in and with the world. Spivak (2004, p. 526) uses the interesting expression of an "uncoercive rearrangement of desires" and gives this as her definition of what education is and what it is about.

By using the opposition of "grown-up"' and "infantile" in this existential way I am not trying to give children a bad name or assume that all adults are able to exist in a grown-up way. On the contrary, by understanding the infantile and the grown-up, the egological and the non-egological as two different ways in which we can engage with what and who is other, I aim to make visible that both options are open for children and for adults - and perhaps we should say that we can only ever know retrospectively whether we have turned out in a particular situation as child-like or adult-like. Our age or the size of our body are no secure indicators for that.

A final observation to make here is that while we do need to pay attention to what is there to do uniquely for each of us, we should not forget that the environments in which we act and live send out 
strong and influential messages as well. To the extent to which modern life is structured by the logic of capitalism, we could say that we live in an environment that is precisely not interested in interrupting and limiting our desires, but rather is focused on the multiplication of our desires, so that we will desire more and therefore will buy more and more. Such an "impulse society" (Roberts, 2014) is precisely not interested in our grown-up-ness but rather prefers that we remain infantile, as that's where the money is being made.

\section{The Educational Work: Interruption, Suspension, and Sustenance}

If this has brought us sufficiently, albeit not perfectly close to an understanding of what it might mean to exist in and with the world in a grown-up way, that is as subject, I now wish to say a few things about the particular educational work ${ }^{4}$ that might contribute to making such an existence possible.

Perhaps the most important point to make, particularly in response to fashionable ideas of education as having to do with the promotion of the child's development, with helping students to develop all their talents and reach their full potential, is that the main principle of education aimed at making a grown-up existence in and with the world possible is that of interruption. This line partly follows from Arendt's reflections on the condition of being subject-as they highlight that our subject-ness is not in our own hands. But it follows most explicitly from the line of thought pursued by Levinas and his suggestion that the event of my subject-ness always appears as an interruption of my immanence, the being for and with myself, and as an awakening out of this drowsy state.

Whereas Levinas's formulations may sound abstract, the main insight here is relatively simple if we see, for example, that we all have talents for good and for evil, and that both morality and criminality can be understood as outcomes of developmental processes. This immediately shows that the educational task can never just be the promotion of the child's development, but needs to be concerned with the question which development is desirable and which is not-which means that the fundamental educational gesture is that of interrupting and questioning development. It also shows that

4 I use the word work here in a very loose sense, with no particular theoretical pretensions. the educational task can never just be about letting students develop all their talents and reach their full potential because, again, what we should be after is the interrogation of talents and potential in order to explore which talents are going to help and which talents are going to hinder grown-up ways of being in the world-which necessarily requires an interruption rather than just letting everything emerge, grow, flow and flourish. To suggest that education is just about supporting the child's development, just about letting each student develop their talents and reach their full potential, is therefore an educational lie-a lie that is not only misleading towards children and students, but is also misleading as a vocabulary for educators to describe and even understand what their task actually is.

Whereas interruption is, in this regard, the most important term as it highlights the fundamental structure of the educational work, it is important to see that interruptions can be performed in a number of different ways-some of them educational (that is aimed at enhancing grown-up-ness) and some of them not. One uneducational way to enact interruption is in the form of what we might call "direct" moral education, where the interruption is enacted as a direct judgement on the side of the educator about the child and their beginnings, that is, in the form of condemnation - "Wrong!"- or praise-“Right!" The problem here is not the feedback in itself, which is important and to a certain degree useful and important, but the fact that the judgement comes from the educator and is applied to the child, as this gives the child no time and no opportunity to appear as subject in relation to such a judgement. The child remains no more than an object of the educator's judgement (or, for readers who can cope with a little play with words: the child remains subjected to the educator's judgement).

We can also put this in terms of the distinction between the desired and the desirable. This distinction, as I have suggested, marks the difference between an infantile and grown-up way of existing, but it is important to read this carefully, as the idea is not that "desires"' are the infantile way and "desirable" the grown-up way. It is rather that the grown-up way is characterized by the "ability" - but perhaps we should call it a willingness or a desire itself-to make and ponder the distinction between one's desires and their possible desirability. The difference, in other words, is that between being an object of one's desires-or in a more precise formulation: being subjected to one's desires-and being a subject of one's desires. 
As long as the educator decides for the child or student which of their desires are desirable, the child and student remain objects of the educator's intentions and activities. The key educational challenge, therefore, is not simply to tell the child or student which of their desires are desirable, but for this question to become a living question in the life of the child or student. This requires anything but direct moral education, but rather hints at the need for opening up literal and metaphorical spaces where the child or student can establish a relationship with their desires, just as it requires the creation of a gap between the desires as they arise and the actions that follow from them. The educational principle here is that of suspension-a suspension in time and space, so we might say-that provides opportunities for establishing relationships with our desires, make them visible, perceivable, so that we can work on them. ${ }^{5}$ This, to make the point one more time, is not a process in which we overcome or destroy our desires-our desires are, after all, a crucial driving force-but select and transform our desires so that we move from being subjected to our desires to becoming a subject of our desires. This is the "uncoercive rearrangement of desires" Spivak (2004, p. 526) writes about which is perhaps a little less uncoercive as her formulation suggests and in addition to rearrangement may also involve a change in the intensity of our desires.

Interruption and suspension both take place in the middle ground with the ambition to keep the student in the middle ground, as it is there that grown-up-ness can only ever be achieved. This means that a third dimension of the educational work-and perhaps this is the most important and most precarious dimension-is that of supporting the student with staying in the difficult middle ground. It involves providing sustenance, in any imaginable form, so that the student can endure the difficulty of existing in and with the world. Yet, as the middle ground is the place where the student encounters the world, part of the educational work here is also to make this encounter possible and give it form-which has to do with pedagogy and curriculum. More specifically the task is to give form to the experience of resistance, so that there is a real possibility to experience the world in its alterity and integrity. It thus also means to provide

5 In Biesta (2017), I discuss in much detail the particular contribution that the arts can make in this process. time to encounter the experience of resistance and work with it—or with the nice interesting expression: to work through it.

The work of the educator here is also to "stage" the experience of resistance as important, meaningful and positive and have an eye for the many different subtle ways in which this can be done. This is not about making things difficult for the sake of making them difficult, but in order to acknowledge its crucial significance vis-à-vis the question of being in the world as subject. Viewed in this way, it is a warning against taking all resistance out of education, by making it flexible, personalised, and completely tailored to the needs of the individual child or student. Such strategies run the risk of isolating the student from the world rather than supporting the student in engaging with the world. To show the student where and how the encounter with the experience of resistance is educationally meaningful-which is not just by telling them that this is so, but can take many different forms - is important in order to keep the child away from the two extremes of world-destruction and self-destruction. Or, in opposition to the "negative" language of "keeping away,"' the work of the educator is to arouse the desire in the student for wanting to stay in the difficult middle ground.

\section{Transforming Power into Authority: The Beautiful Risk of Teaching}

If interruption, suspension and sustenance are, in a sense, rather concrete activities, there is one further dimension of the work of the teacher that is barely, if at all, in the hands of the teacher. This dimension has to do with the transformation of power into authority. The issue here is that although educational interruptions are "aimed" at the subject-ness of the student, when enacted they appear as acts of power, at least in those cases where students did not ask for such interruptions to occur-which is probably where all education starts. The ambition of educational interruptions is to "turn" students towards the question whether what they desire is what they should be desiring, and much of the work of the educator is about creating time, space and forms so that students can encounter their desires, examine their desires, select and transform them. Whereas the question of the desired and the desirable is introduced by the teacher-as a powerful interruption - the ambition 
is that this question becomes a living question in the life of the student. At stake here is the question as to what should have authority in our lives, and the question of authority is precisely about coming into dialogue with what and who is other. It is about letting something or someone have power in our lives. It is about authorising what and who is other, it is to let it speak, so to say, to make it into an author.

What we hope as teachers whose teaching is aimed at the subject-ness of our students is that at some point the student will turn back to us and acknowledge that what in the first instance appeared as an unwanted interruption-an act of power-did actually contribute to their grown-up existence in and with the world, their grown-up subject-ness. When such a turning happens, and only when it happens, we can say that power-which is always monological and onedirectional-has transformed into authority-which is always dialogical and relational (Bingham, 2008). But we never know whether such a "return" may happen, and we never know when such a "return" may happen, which may well be long after the student has disappeared from our view and our (professional) life. This means that any teaching aimed at the subject-ness of the student is first of all risky in that its outcomes are unpredictable. But it is also risky because we, as teachers, risk ourselves, as we are always enacting power without often knowing whether this power will "return" as authority, as accepted and acknowledged power. But this should not prevent us from taking this risk, because with out it education would not happen either. It rather should help us to understand much better what the risky nature of teaching and education more generally is, if it is aimed at the subject-ness of the student, or if it is aimed at arousing the desire in another human being for wanting to exist in the world in a grown-up way.

\section{References}

Andreotti, V. (2011). Actionable postcolonial theory in education. New York, NY: Palgrave/Macmillan.

Arendt, H. (1958). The human condition. Chicago, IL: The University of Chicago Press.

Bauman, Z. (1993). Postmodern ethics. Oxford, UK: Wiley-Blackwell.
Biesta, G. (2006). Beyond learning. Democratic education for a human future. Boulder, CO: Paradigm Publishers.

Biesta, G. (2010a). A new "logic" of emancipation: The methodology of Jacques Ranciere. Educational Theory 60(1), 39-59.

Biesta, G. (2010b). How to exist politically and learn from it: Hannah Arendt and the problem of democratic education. Teachers College Record, 112(2), 558-577.

Biesta, G. J. (2017). Letting art teach: Art education after Joseph Beuys. Arnhem: ArtEZ Press.

Biesta, G. \& Säfström, C. (2011). A manifesto for education. Policy Futures in Education 9(5), 540-547.

Bingham, C. (2008). Authority is relational. Albany, NY: SUNY Press.

Critchley, S. (1999). Ethics, politics, subjectivity. London/ New York: Verso.

Levinas, E. (1969). Totality and infinity. An essay on exteriority. Pittsburgh, PA \& The Hague: Duquesne University Press \& Martinus Nijhoff. (Original work published in 1961).

Levinas, E. (1985). Ethics and infinity. Conversations with Philippe Nemo. Pittsburgh, PA: Duquesne University Press.

Levinas, E. (1989). Revelation in the Jewish tradition. In S. Hand (Ed.), The Levinas reader (pp.190-211). Oxford, UK: Blackwell.

Lingis, A. (1994). The community of those who have nothing in common. Bloomington, IN: Indiana University Press.

Meirieu, P. (2007). Pédagogie: Le devoir de résister. Issy-lesMoulineaux: ESF éditeur.

Roberts, P. (2014). The impulse society. What is wrong with getting what we want. London, UK: Bloomsbury.

Sartre, J. (2007[1946]). Existentialism is a humanism. New Haven, CT: Yale University Press. (Original work published in 1988).

Spivak, G. (1988). Can the subaltern speak? In C. Nelson \& L. Grossberg (Eds.), Marxism and the interpretation of culture (pp. 271-313). Urbana, IL: University of Illinois Press.

Spivak, G. (2004). Righting the wrongs. South Atlantic Quarterly, 103(2/3), 523-581. 


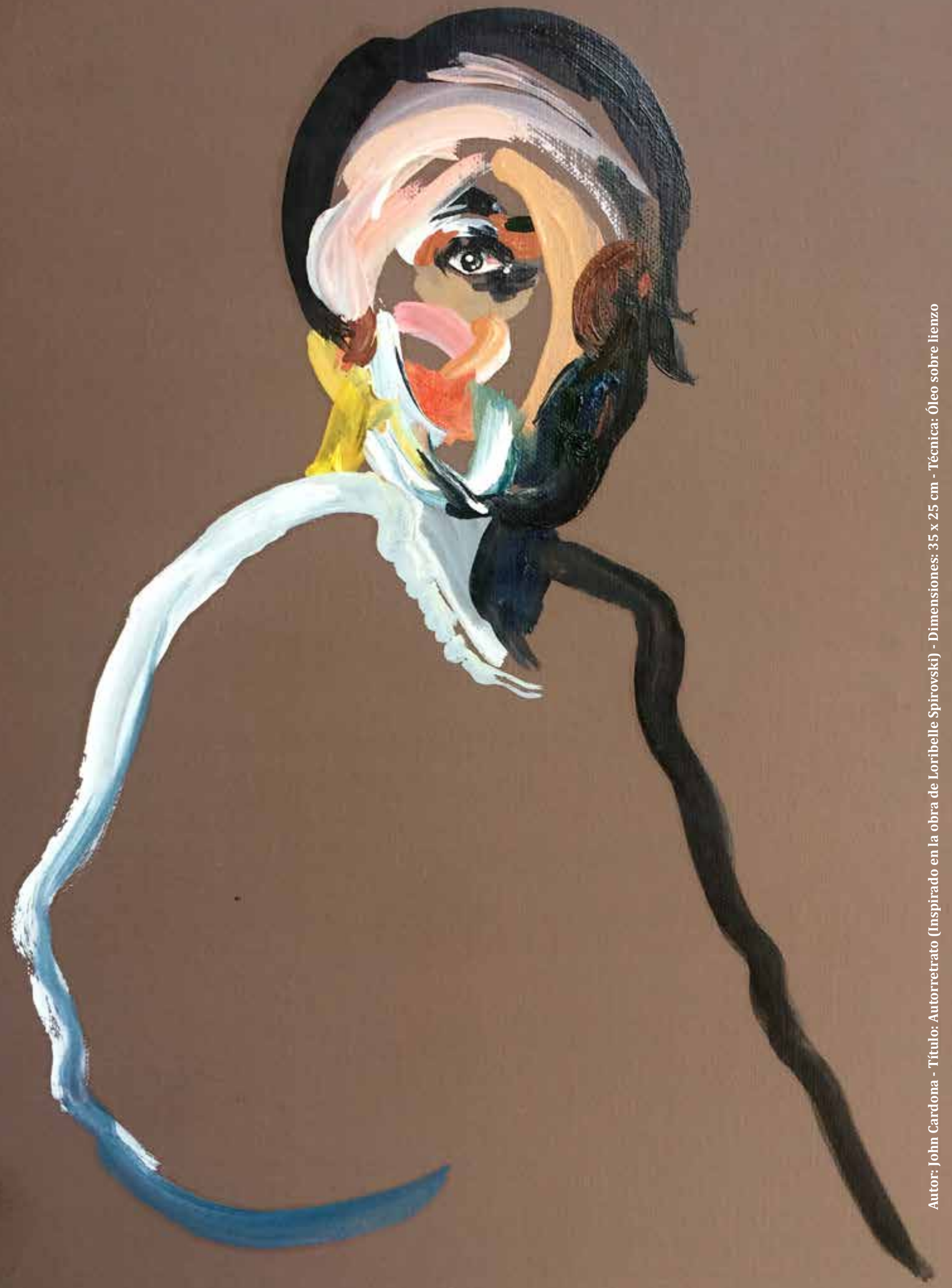

